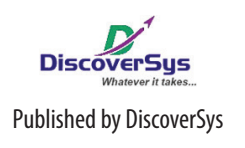

${ }^{1}$ Program Studi Magister IImu Kesehatan Masyarakat Universitas Udayana,

${ }^{2}$ Bagian IImu Kedokteran Komunitas dan IImu Kedokteran Pencegahan Fakultas Kedokteran Universitas Udayana

*Korespondensi penulis: Dewa Nyoman Wirawan, Program Studi Magister IImu Kesehatan Masyarakat Universitas Udayana, Bagian IImu Kedokteran Komunitas dan IImu Kedokteran Pencegahan Fakultas Kedokteran Universitas Udayana

wirawandewa48@gmail.com

\title{
Mengembalikan Kondisi Bali Menjadi Bebas Rabies
}

\author{
Dewa Nyoman Wirawan ${ }^{1,2^{*}}$
}

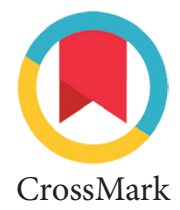

Rabies pada manusia yang ditularkan oleh anjing menjadi masalah kesehatan masyarakat yang banyak muncul belakangan ini di kawasan Asia. ${ }^{1}$ Rabies pertama kali dilaporkan di Indonesia pada tahun 1884 dan saat ini endemis di 24 provinsi dari 33 provinsi yang ada. ${ }^{2}$ Sebelum tahun 2008, Bali dinyatakan bebas dari rabies karena sebelumnya tidak pernah dilaporkan adanya kasus rabies pada manusia maupun hewan. ${ }^{2}$ Kasus rabies pertama pada manusia dan anjing di Bali dijumpai Bulan Oktober tahun 2008 di Jimbaran, Kuta Selatan, Kabupaten Badung. ${ }^{1}$ Setelah kasus pertama, rabies dengan cepat menular ke kota/kabupaten lain di Bali. Pada tahun 2009, kasus rabies pada manusia dan anjing dilaporkan di Kabupaten Tabanan, Buleleng dan juga Karangasem yang jaraknya cukup jauh dari Desa Jimbaran, Kuta Selatan. ${ }^{1}$

Jumlah kasus rabies pada manusia yang dilaporkan ke Dinas Kesehatan Provinsi Bali pada tahun 2008 sebanyak empat orang, 32 orang pada tahun 2009 dan melonjak menjadi 83 orang pada tahun 2010. ${ }^{3}$ Secara kumulatif, sampai dengan 19 Desember 2015 jumlah kasus rabies yang dilaporkan ke Dinas Kesehatan Provinsi Bali berjumlah 174 orang dan semua penderita meninggal (case fatality rate sebesar 100\%). Pemberian vaksinasi rabies pada anjing langsung dilaksanakan pada tahun 2008 namun jumlahnya hanya 6.567 anjing, kemudian meningkat pada tahun 2009 dan puncaknya pada tahun 2010 yaitu sebanyak 474.332 anjing, tetapi cakupannya menurun setelah tahun $2010 .{ }^{3}$ Setelah dilakukan vaksinasi pada sebagian besar anjing, kasus rabies pada manusia mulai menurun sampai hanya satu kasus pada tahun 2013. ${ }^{3}$ Jumlah populasi anjing yang ada di Bali diperkirakan sekitar 500.000 ekor. $^{3}$ Bila perkiraan ini mendekati kebenaran maka cakupan vaksinasi pada anjing pada tahun 2010 adalah sekitar 95\%. Peningkatan jumlah kasus rabies pada manusia tahun 2014 dan 2015 sangat berkaitan dengan cakupan vaksinasi pada anjing yang menurun setelah tahun $2010 .^{3}$

Berdasarkan rekomendasi WHO, bila 70\% dari semua anjing yang ada bisa mendapatkan vaksin secara rutin (setiap tahun), maka semua anjing yang ada di Bali akan terlindungi dari rabies. ${ }^{4} \mathrm{Hal}$ ini disebut dengan herd immunity, yaitu pemberian vaksinasi pada sebagian populasi yang mampu memberi perlindungan pada semua anggota populasi termasuk yang belum mendapat vaksinasi. WHO juga mengemukakan bahwa epidemi rabies tidak tergantung dari berkurangnya populasi anjing di suatu wilayah. Beberapa kejadian epidemi rabies di negara lain banyak terjadi pada suatu daerah dimana populasi anjingnya tidak terlalu banyak. ${ }^{4}$ WHO merekomendasikan bahwa cara yang paling cost-effective untuk menanggulangi epidemi rabies pada hewan maupun manusia adalah dengan melakukan vaksinasi masal pada hewan (anjing) karena harga vaksin untuk anjing jauh lebih murah dibandingkan harga VAR untuk manusia. ${ }^{4}$ Harga VAR seperti tercantum di E-Katalog adalah Rp. 78.000,- (tahun 2015) untuk satu kali suntik dan untuk 4 kali suntik maka biaya yang diperlukan untuk pengadaan VAR adalah Rp. 312.000,- per pasien. Harga vaksin untuk anjing adalah sekitar Rp. 110.000,- untuk 10 ekor anjing atau Rp. 11.000,- per satu ekor anjing. Bila jumlah anjing yang divaksinasi adalah $70 \%$ dari sekitar 500.000 ekor, maka biaya yang diperlukan adalah sekitar 3,8 milyar dalam satu tahun. Jumlah rata-rata gigitan anjing dalam satu tahun diperkirakan sekitar 50.000, dan bila semua dari mereka diberikan VAR maka biaya untuk VAR saja adalah sekitar 15 milyar dalam satu tahun. Biaya tersebut hanya untuk pembelian vaksin dan belum memperhitungkan biaya operasional lainnya. Dari perhitungan kasar ini, amat jelas kelihatan bahwa melakukan vaksinasi pada sekitar $70 \%$ anjing yang ada di Bali jauh lebih cost-effective dibanding pengadaan VAR.

Penanggulangan epidemi rabies yang dilaksanakan di Bali selama ini antara lain: 1) mempersiapkan sarana dan prasarana yang memadai dalam tata laksana pasien dengan gigitan anjing (post exposure treatement) termasuk pemberian vaksin anti rabies (VAR) dan juga pemberian serum anti rabies (SAR) bagi mereka yang memenuhi indikasi medis; 2) melakukan vaksinasi masal pada anjing; 3) melakukan sterilisasi (kastrasi) pada anjing dan 4) melakukan penyuluhan kepada masyarakat.

Tantangan yang dihadapi cukup banyak antara lain adalah sebagai beriut. 1) Pemahaman masyarakat yang masih rendah. Dari 174 kasus rabies yang meninggal sejak tahun 2008 sampai dengan tahun 2015, hanya 14 orang yang pernah mendapatkan VAR. Hal ini menunjukkan bahwa masih banyak masyarakat tidak segera mendatangi tempat-tempat pelayanan kesehatan setelah digigit anjing untuk mendapatkan perawatan pada luka gigitan dan untuk mendapatkan VAR. 2) Jumlah 
populasi anjing yang cukup banyak di Bali berkaitan dengan aspek kultural dimana masyarakat telah terbiasa untuk memelihara anjing. Selain itu, anjing juga diperlukan oleh masyarakat sebagai penjaga rumah atau lahan pertanian/perkebunan (security). 3) Karena diperlukan sebagai security, maka anjing di Bali biasa dilepas dan tidak dikandangkan. Selain biasa dilepas, banyak pula anjing yang lahir begitu saja dan kemudian tanpa pemilik yang jelas. Populasi anjing yang seperti ini termasuk anjing tanpa pemilik ("anjing liar"). 4) Sejumlah anjing dibunuh ketika terjadi epidemi, tetapi setelah epidemi mereda, polulasi anjing akan kembali seperti sebelumnya karena aspek kultural dan kebutuhan masyarakat untuk memelihara anjing. 5) Ketika banyak anjing dibunuh, sebagian dari anjing-anjing tersebut adalah yang sudah mendapat vaksinasi dan hal ini akan menurunkan herd immunity 70\%. 6) Masuknya anjing dari luar Bali amat sulit dicegah karena banyaknya cara-cara penyelundupan anjing, banyaknya pintu masuk termasuk anjing yang biasa dibawa oleh para nelayan. 7) Harga VAR cukup mahal dan sering ada hambatan dalam pengadaannya. 8) Pengadaan vaksin anjing relatif lebih murah tetapi banyak tantangan untuk memberikan vaksinasi setiap tahun kepada sekurang-kurangnya $70 \%$ anjing yang ada di Bali karena kondisi geografis di daerah pedesaan (perkebunan), kesulitan menangkap anjing untuk divaksinasi, pemberian tanda pada anjing yang sudah mendapat vaksin dan masalahmasalah teknis lainnya.

Upaya-upaya yang bisa ditempuh untuk kembali pada kondisi Bali sebelum tahun 2008 yaitu bebas rabies, antara lain seperti berikut. 1) Melakukan vaksinasi rutin setiap tahun pada sekurangkurangnya $70 \%$ dari populasi anjing. Hal ini juga akan meningkatkan citra Bali di manca negara sehingga turis tidak merasa khawatir untuk datang ke Bali. 2) Karena vaksinasi anjing harus dilakukan setiap tahun, maka agar pelaksanaannya bisa berkelanjutan dan bisa mencapai cakupan $70 \%$, perlu dibentuk Tim Rabies Tingkat Desa. 3) Tim Rabies Tingkat Desa perlu dilatih dalam hal: a) keterampilan pendekatan kepada masyarakat, b) pemetaan jumlah anjing di masing-masing desa, c) teknik menangkap anjing yang sulit ditangkap, d) pemberian tanda yang baik pada anjing sesudah diberikan vaksinasi, e) teknik surveilans, f) sistem pencatatan dan pelaporan serta g) cara-cara pertolongan pertama yang benar bila ada anggota masyarakat yang digigit anjing. 4) Sebelum dilakukan pada semua desa, diperlukan pelatihan di 3-4 desa sebagai percontohan. Kelemahan dan kekurangan dalam percontohan kemudian disempurnakan sebelum diterapkan pada jumlah desa yang lebih banyak. 5) Pelatihan hendaknya dilaksanakan oleh pelatih profesional yang telah berpengalaman dalam bidang pemberdayaan masyarakat, pelatihan partisipatif dan penanggulangan rabies. 6) Penanggulangan rabies di masing-masing desa hendaknya dirancang dalam penyusunan Rencana Pembangunan Jangka Menengah Desa (RPJM Desa) dan Rencana Kerja Pemerintah Desa (RKP Desa) dan insentif untuk Tim Rabies Tingkat Desa dianggarkan dalam Anggaran Pendapatan dan Belanja Desa (APB Desa) yang dananya bersumber dari Alokasi Dana Desa (ADD). 7) Tata laksana penanggulangan rabies pada manusia (pengadaan VAR, keberlanjutan rabies center, pelatihan-pelatihan kepada petugas kesehatan serta kegiatan lainnya) yang telah dilaksanakan selama ini hendaknya tetap dipertahankan atau disempurnakan.

\section{DAFTAR PUSTAKA}

1. Towsend SE, Sumantera IP, Pujiatmoko, Bagus GN, Brum E, et al. Designing Program for Eliminating Canine Rabies from Island: Bali, Indonesia as a Case Study. PloS Negl Trop Dis August 2013; 7(8): e2372 doi:10.1371/ journal.pntd.0002372.

2. Putra AAG, Hampson K, Girardi, J, Hiby E, Knobel D, et al. Response to a Rabies Epidemic, Bali, Indonesia, 20082011. Emerging Infectious Disease, April 2013; 19(4): 648-651.

3. Pemerintah Provinsi Bali. Peraturan Daerah Provinsi Bali Nomor 1 Tahun 2014 tentang Rencana Pembangunan Jangka Menengah Daerah Provinsi Bali Tahun 2013-2018: II-65-II-67.

4. World Health Organization. Expert Consultation on Rabies: Fisrt Report. Geneva: the Organi-zation, 2005.

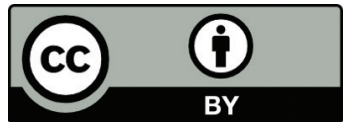

This work is licensed under a Creative Commons Attribution 